European Research Studies,

Volume XIII, Issue (1), 2010

\title{
Distribution and Development in Developing Countries: An Empirical Assessment
}

\author{
Minh Quang DAO ${ }^{1}$
}

I would like to thank Christian Dippel at the $43^{\text {rd }}$ annual conference of the Canadian Economics Association in Toronto for his valuable comments on and suggestions for an earlier version of this paper and Thi Minh Chi Le for her support during the completion of this paper.

\begin{abstract}
:
This paper examines the effect of income distribution on growth in developing countries. Based on data from the World Bank and the United Nations Development Programme, we use a sample of twenty-eight developing economies and find that income distribution does not affect growth in these countries, unlike the results of previous studies by Alesina and Rodrik (1994). Neither do we find that the level of democracy in a country has a statistically significant impact on growth. We observe that the coefficient estimate of one independent variable does not have the anticipated sign due to the severe degree of multicollinearity among statistically significant explanatory variables. Regression results show that the total fertility rate, the initial level of per capita GDP, and the ratio of female to male literacy rate, taken together, do linearly influence growth in developing economies. Statistical results of such empirical examination will assist governments in those countries identify areas that need to be improved upon in order to stimulate economic development.

Data for all variables are from the 1978 World Development Report, the World in 2007, and the 1999, 2000, and 2007/08 Human Development Reports.

We apply the least-squares estimation technique in a multivariate linear regression. We also note that the severe degree of multicollinearity among explanatory variables may have caused their coefficient estimates to have the wrong sign.
\end{abstract}

Keywords: Total Fertility Rate, Per Capita GDP, Female to Male Literacy Ratio, Income Inequality, Developing Countries, Index of Democracy, Primary Enrollment Rate.

JEL Classifications: $012,015,040$

\section{Introduction}

For quite some time economists have been interested in the relationship between income distribution and economic development. One of the most famous works on this is Kuznets' (1966) inverted-U hypothesis, according to which income

\footnotetext{
${ }^{1}$ Professor of Economics, Eastern Illinois University, 600 E. Lincoln Avenue, Charleston, IL 61920, USA
} 
distribution tends to worsen during the early stages of economic growth but will improve in the later stages. This may be due to the fact that early growth tends to occur in the modern industrial sector with limited employment concurrent with high wages and productivity. However, many development economists have argued that empirical studies have shown that higher per capita incomes may be concomitant with falling inequality using examples of countries such as Taiwan, South Korea, China, Costa Rica, and Sri Lanka.

The current study, however, empirically examines the reverse causality from income distribution to economic development. Using data from the World Bank and the United Nations Development Programme for a sample of twenty-eight developing economies for the period from 1975 to 2005, we find that neither income distribution nor the level of democratic development is statistically significant in explaining economic growth in these countries.

We are able to show that economic development is linearly dependent on the total fertility rate, the initial level of per capita income, and the ratio of female to male literacy. Statistical results of such empirical examination will help governments in developing countries identify areas that need special attention in order to foster economic growth.

This paper is organized as follows. In the next section, a selected review of the literature on the impact of income distribution on economic growth is discussed. This is followed by the formulation of a statistical model to be estimated. Theoretical underpinnings for the inclusion of explanatory variables are presented in this section. Statistical results are reported in the subsequent section. A final section gives concluding remarks as well as policy recommendations.

\section{A selected review of the literature}

There have been two recent strands of work on income distribution and growth. One looks at the role of imperfect capital markets (see, e.g. Galor and Zeira (1988) and Banerjee and Newman (1991), while the other focuses on the effects of the political outcome generated by a certain distribution of income (see, e.g., Alesina and Rodrik (1991), Persson and Tabellini (1991), Saint-Paul and Verdier (1991), and Perotti (1991)). Murphy, Shleifer, and Vishny (1989) argue that the process of industrialization of the now developed economies requires two conditions. First, a leading sector such as agriculture or exports must grow rapidly to provide the source of home demand for manufactures. Second, the emergence of a middle class via a broad distribution of income is required in order to sustain industrialization, and hence growth.

Galor and Zeira (1993) attribute the persistent differences in per capita income across nations to the presence of imperfect credit markets and invisibilities in investment in human capital causing the initial distribution of wealth to impact aggregate income and investment both in the short run and in the long run. In the same vein, Perotti (1993) develops a model that analyzes the effect of income distribution on growth when growth is driven by investment in human capital while individual voters determine the extent of redistribution in the economy via the 
political process. He finds an inverted-U relation between inequality and income levels using cross-section data. Using an endogenous growth model Bertola (1993) shows that when agents are heterogeneous in terms of how much of their income is derived from accumulated factors of production ("capital") versus nonaccumulated factors, the implementation of growth-oriented policies depends on how capital-poor the median voter is vis-à-vis the representative agent in the economy. Alesina and Rodrik (1994) develop a simple model of endogenous growth to show that the greater wealth and income inequality, the lower growth. They use data on the distributions of both income and land (as a substitute for wealth) from several samples of countries to examine their effect on growth for the 1960-85 period.

The present study seeks to identify the sources of per capita income growth across developing countries and empirically estimate their effect in order to assist policy makers recognize areas that need special attention in order to foster economic growth. In the process we wish to empirically analyze the effect of income distribution on growth using a sample of twenty-eight developing countries [1].

\section{The statistical model}

If we assume that various exogenous factors linearly affect per capita GDP growth in a developing country, we can state the following statistical model:

$$
\text { Growth }=\beta_{0}+\beta_{1} \text { TFR75 }+\beta_{2} \text { PcGDP75 }+\beta_{3} \text { F/MLitrcy }+\beta_{4} \text { TopBot } 20+
$$
$(-)$
$(-)$
$(+)$
$(-)$

$\beta_{5}$ DemIndex $+\beta_{6}$ Primary $+\varepsilon$ (1)

(+) (+)

where Growth = Average annual growth rate of per capita GDP, 1975-2005

TFR75 = Total fertility rate in 1975 .

PcGDP75 = Per capita GDP level in 1975.

$F / M L i t r c y=$ Ratio of female to male literacy rate in 1970 .

TopBot20 $=$ Ratio of share of income by top quintile to share of income by bottom quintile, 1980-1994.

DemIndex $=$ Level of democracy/autocracy, ranging from -10 (strongly autocratic) to +10 (strongly democratic) in 1975 .

Primary $=$ Primary school enrollment ratio in 1975 .

While economic theory has not yet clearly determined the causality between income and population growth making inference about the effect of the latter on the former difficult, the presence of limited resources coupled with diminishing returns implies a negative impact of population growth on economic growth. We expect that the higher the total fertility rate in a developing country, the lower the average annual growth rate of per capita GDP. To capture the tendency for poor countries to grow faster than rich countries, termed $\beta$-convergence, as shown by Barro and Sala $i$ Martin (1990) we include the initial (1975) level of real per capita GDP. The primary reason for this convergence result in neoclassical growth models is 
diminishing returns to physical capital. We thus expect that the coefficient estimate on this variable to have a negative sign.

Romer (1990) examines the role of human capital as a key input in the production of knowledge leading to technological progress. Countries with greater initial stocks of human capital tend to grow faster since they are exposed to a higher rate of introduction of new products. In addition, Nelson and Phelps (1966) point out that a follower country endowed with a greater stock of human capital are more capable of catching up more quickly to the technological leader and hence are more likely to grow faster. Following Barro (1991) we use the 1975 primary school enrollment ratio as a proxy for initial human capital. We caution the reader that this independent variable may be strongly correlated with the total fertility rate variable, as human capital is more productive in the production of goods and additional human capital as opposed to producing more offsprings.

There is much empirical evidence that discrimination against women in education hinders the economic development process while helping to perpetuate social injustice. It has been shown that in most developing countries the rate of return on women's education is higher than that on men's. In addition, expanding women's education leads to higher labor force participation and lower fertility, contributing to growth. More educated mothers also generate multiplier effects on the quality of a country's future labor force via improved child health and nutrition. Finally, as education significantly improves women's role and status in developing economies, this may enhance their ability of breaking the vicious cycle of poverty and inadequate schooling. We thus expect that the higher the female to male ratio of literacy rate, the higher the growth rate of per capita GDP.

Alesina and Rodrik (1994) use a dummy variable to test for any systematic difference in the average rates of growth of democracies and nondemocracies. We choose to include a democracy index variable in order to see if economic growth responds to varying degrees of participation in the political process. We argue that as countries become more democratic, their economies tend to grow faster. We thus expect the coefficient estimate on this variable to have a positive sign.

Since income Gini coefficients are not available for all countries in the data set for the same year we choose to use as a measure of income distribution the ratio of the share of income by the top quintile in the population to that by the poorest quintile. Data for this variable are available for the period from 1980 to 1994.

Data for all variables are from the 1978 World Development Report, http://earthtrends.wri.org/text/environmental-governance/variable-509.html, and the 1999, 2000, and 2007/2008 Human Development Reports.

\section{Empirical results}

Table 1 gives least-squares estimates of regression coefficients in equation (1) for a sample of twenty-eight developing countries. The goodness of fit of the model to the data is very good as indicated by the value of 0.561 of the adjusted coefficient of determination. We observe that all variables except the 1975 total fertility rate, the ratio of female to male literacy rate, and the 1975 per capita GDP 
are statistically not significant at any commonly used level. As expected, due to multicollinearity among independent variables, the coefficient estimate of the ratio of female to male literacy rate variable does not have the expected sign. The results suggest that more democratic societies tend to experience higher economic growth, but as pointed out by Alesina and Rodrik (1994), there is no a priori ground to believe that there should be any systematic correlation between regime type and growth [2], as indicated by the statistical insignificance of this explanatory variable. The coefficient estimate on the 1975 primary school enrollment ratio variable does have the expected positive sign but the variable itself does not help explain crosscountry variations in per capita GDP growth rates. Unlike results of studies by Galor and Zeira (1993) and by Alesina and Rodrik (1994) we find that the relationship between inequality and growth is positive at all levels of income, not just at low ones. However, such a relationship is statistically nonsignificant.

Table 1: Empirical Results (Full Model)

Right-hand-side Variable

Coefficient Estimate

t-

Statistic

Intercept

5.402

TFR75

5.667*

$P c G D P 75$

2.688*

F/MLitrcy

$1.987 * *$

TopBot 20

0.426

DemIndex

0.505

Primary

0.608

Adjusted $\mathrm{R}^{2}=0.561$

*Significant at the 1 percent level.

**Significant at the 5 percent level.

Using the backward elimination stepwise method we arrive at a revised model the regression results of which are reported in Table 2. We note that the goodness of fit of the model to the data is better as indicated by the higher value of 0.605 of the adjusted coefficient of determination. We observe that all variables are statistically significant at the 5 percent level or lower. 
All else equal, a one-percent increase in the total fertility rate in 1975 is expected to lead to a 1.4 percent reduction in the average annual per capita GDP growth rate for the period from 1975 to 2005. Holding the total fertility rate in 1975 and the female to male literacy ratio constant, a $\$ 10$ dollar increase in purchasing power parity GDP per capita in 1975 is expected to reduce growth by 0.01 percent annually. As indicated earlier, due to severe multicollinearity among explanatory variables, the coefficient estimate on the female to male literacy ratio does not have the expected sign. The extent of this problem is reported by the sample correlation coefficient matrix on Table 3.

Table 2: Empirical Results (Revised Model)

Right-hand-side Variable

Coefficient Estimate

t-

Statistic

Intercept

11.714

6.192

TFR75

6.363*

PcGDP75

$-0.001$

2.916*

F/MLitrcy

$-0.024$

$2.033^{* *}$

$\overline{\text { Adjusted }}^{2}=0.605$

*Significant at the 1 percent level.

**Significant at the 5 percent level.

Table 3: Sample Correlation Matrix

\begin{tabular}{lrrr}
\hline & \multicolumn{1}{c}{ TFR75 } & PcGDP75 & F/Mlitrcy \\
\hline TFR75 & 1 & & \\
PcGDP75 & -0.508 & 1 & \\
& $\mathbf{- 3 . 0 1 2}$ & & \\
F/Mlitrcy & -0.681 & 0.572 & 1 \\
& $\mathbf{- 4 . 7 4 6}$ & $\mathbf{3 . 5 6 1 6}$ &
\end{tabular}

Note: Bold

imply statistical significance at the 10 percent or lower level.

t-statistics

The fact that we obtain statistical results that seem to be inconsistent with our hypothesis about the impact of the ratio of female to male literacy rate variable on income growth could be due to a simultaneity bias or a high degree of 
multicollinearity among explanatory variables. This undoubtedly makes the interpretation of the coefficient estimate on the ratio of female to male literacy rate variable more difficult.

\section{Conclusion}

In this paper we use a statistical model and data from a sample of twentyeight developing economies to empirically analyze the impact of several explanatory variables on per capita GDP growth. From the statistical results we are able to draw the following conclusions:

1. Within the set of developing economies in this study, poor countries tend to grow faster than rich countries, i.e. the data are consistent with the concept of $\beta$-convergence. An interesting extension of the present study would be to include developed countries and empirically examine whether this type of convergence applies to developing countries catching up with developed ones.

2. Developing countries with higher fertility rates do experience slower economic growth. Thus, governments in these countries need to design policies aimed at encouraging the use of contraception and expanding educational as well as employment opportunities for women in order to stimulate economic growth.

\section{References:}

1. Alesina, R. and Rodrik, D. (1991), "Distributive Politics and Economic Growth," Cambridge, MA: National Bureau of Economic Research Working Paper No. 3668.

2. Growth", Quarterly Journal of Economics, Vol. 109 No. 2, pp. 465-90.

3. Banerjee, A. and Newman, A. (1991), "Risk Bearing and the Theory of Income Distribution", Review of Economic Studies, Vol. 58, pp. 211-35.

4. Barro, R. (1991), "Economic Growth in a Cross Section of Countries," Quarterly Journal of Economics, Vol. 106 No. 2, pp. 407-43.

5. and Sala-i-Martin, X. (1990), "Public Finance in the Theory of Economic Growth," unpublished manuscript.

6. Bertola, G. (1993), "Factor Shares and Savings in Endogenous Growth", American Economic Review, Vol. 83, No. 5, pp. 1184-98.

7. Galor, O. and Zeira, J. (1988), "Income Distribution and Economic Growth", Brown University Working Paper No. 89-25.

8. (1993), "Income Distribution and Macroeconomics," Review of Economic Studies, Vol. 60, pp. 35-52.

9. Kuznets, S. (1966), Modern Economic Growth. New Haven: Yale University Press.

10. Murphy, K.M., Shleifer, A., and Vishny, R. (1989), "Income Distribution, Market Size, and Industrialization," Quarterly Journal of Economics, Vol. 104, No. 3, pp. 537-64. 
11. Nelson, R.R. and Phelps E.S. (1966), "Investment in Humans, Technological Diffusion, and Economic Growth," American Economic Review Proceedings, Vol. 56, pp. 69-75.

12. Perotti, R. (1991), "Income Distribution, Politics, and Growth: Theory and Evidence," mimeo, Columbia University.

13. (1993), "Political Equilibrium, Income Distribution, and Growth," Review of Economic Studies, Vol. 60, pp. 755-76.

14. Persson, T. and Tabellini, G. (1991), "Is Inequality Harmful for Growth," Cambridge, MA: National Bureau of Economic Research Working Paper No. 3599.

15. Romer, P.M. (1990), "Endogenous Technological Change," Journal of Political Economy, Vol. 98, pp. S71-S102.

16. Saint-Paul, G and Verdier, T. (1991), "Education, Democracy, and Growth," mimeo, DELTA, Paris.

17. United Nations Development Programme (1999), Human Development Report 1999: Globalization with a Human Face. New York: Oxford University Press.

18.

2000: Human Rights and Human Development. New York: Oxford University Press.

19.

Change: Human Solidarity in a Divided World. New York: Oxford University Press.

20. World Bank (1978), World Development Report 1978, Oxford University Press, New York, NY.

21. World Resources Institute (2004), http://earthtrends.wri.org/text/environmentalgovernance/variable-509. html

\section{ENDNOTES:}

1. The sample consists of the following countries: Algeria, Bolivia, Brazil, Chile, Colombia, Costa Rica, Côte d'Ivoire, Dominican Republic, Ecuador, Egypt, Ghana, Guatemala, Honduras, Indonesia, Jamaica, Kenya, Mexico, Nepal, Nicaragua, Niger, Pakistan, Panama, Rwanda, Sri Lanka, Thailand, Tunisia, Venezuela, and Zambia.

2. Alesina and Rodrik (1994) give two reasons why this may be the case. First, even in nondemocratic societies there may still be redistributive pressures. Second, the nature of a political regime and its preferences may dictate the weight attached to economic growth. For more details on this, see Alesina and Rodrik (1991). 